\title{
Issue of pendency of cases in Indian courts and way forward
}

\author{
*Prof. (Dr.) Prakash N. Chaudhary, ${ }^{1}$ Dr. Vikas A. Barbate ${ }^{2}$, Adv. Owi P. Chaudhary ${ }^{3}$ \\ ${ }^{1}$ Vice Principal, Professor\& Head, Dept. of Business Laws, Ness Wadia College of \\ Commerce, Pune - 411 001(India) \\ ${ }^{2}$ Associate Professor, ASM's Institute of Professional Studies, Pimpri, Pune-4110018 (India) \\ ${ }^{3}$ Advocate, District and Sessions Court, Pune (India) \\ 1'pncwadia@gmail.com, ${ }^{2}$ vikasbarbate@asmedu.org, ${ }^{3}$ owichaudhary@gmail.com
}

\begin{abstract}
'Delay defeats the justice' is the well-known saying in the legal arena. Indian judiciary is severely burdened due to large number of pending cases. Delay in justice delivery system creates sense of insecurity in the minds of citizens. Judiciary is one of the very important pillars of the democratic society to dispense the justice to the needy.

"Justice Delayed is Justice Denied" is another fact of the society. There are various reasons of delay in disposal of cases in Indian Courts. Problem of pendency of cases is a matter of concern for entire judicial system in the Country. This article tries to identify the reasons of delay in disposal of cases in the Indian courts and suggest probable solutions to resolve the issue of pendency.
\end{abstract}

Effective use of alternative disputes mechanism and proactive measures by all stakeholders to curb the delay in the legal proceedings would help to save time during the actual conduct of the case and justice delivery system can become more effective resulting into timely disposals of cases thereby ensuring faith of fellow citizens in the judicial administration

Key words: pendency, judicial administration, alternative disputes Redressal (ADR), mediation, conciliation, Information Technology, E-Courts

\section{Introduction:}

Pendency or backlog of the cases is prevalent in India at all levels of the judicial hierarchy, i.e., The Supreme Court, the High Court, and the District or Subordinate courts. In the recent survey it has been observed that there are 4.5 crores of cases pending in the Indian Courts at various levels. There are 70,239 cases pending in the Supreme Court as on 1.1.2022. National Judicial Data Grid shows that there are 4.11 crores cases pending in the high courts and lower courts. In the circumstances it has become a serious concern to tackle the issue of pendency of cases in the courts with time-bound strategy to deal the problem. 
Objectives: 1 . To study and identify the state of affairs of pending of cases in the Indian Courts.

2. To identify the reasons of such delay and suggest strategy or remedies to overcome this menace.

Methodology: The present study is exploratory in nature and mainly based on the secondary data.

It is well established fact that Indian courts take lot of time in deciding the cases. Pendency of cases in the courts beyond reasonable time creates certain questions and concerns about the judicial administration.

\section{Major reasons of delay in deciding cases:}

The problem of pendency is due to manifold reasons which can be enumerated as follows;

1. Lack of adequate judges: The ratio of judges and population is low in India in comparison with other advanced countries. The vacant position of judicial officers are not filled on time and this fact worsens the situation more. There are chances that burden of more cases for disposal would adversely affect the quality of judgments. In $120^{\text {th }}$ Law Commission Reports, it was observed that in United States the judge-population ratio is 107 judges per million population, the current approximate Indian ratio is 10.5 judges per million population i.e. about one tenth of the ratio in the U.S. This shows the ideal requirement of judges in the country. Moreover the Indian judiciary faces a problem of an increasing number of cases to be decided and a large number of vacancies across all levels to be filled. The Supreme Court Collegium recently recommended the appointment of 129 High Court judges, soon after the appointment of seven judges to the Supreme Court. ${ }^{1}$

Between 2010 and 2020, pendency across all courts grew by $2.8 \%$ annually. As of September 15, 2021, over 4.5 crore cases were pending across all courts in India. Of these, $87.6 \%$ cases were pending in subordinate courts and 12.3\% in High Courts. Between 2019 and 2020, pending cases increased by $20 \%$ in High Courts and $13 \%$ in subordinate courts. ${ }^{2}$

However in 2020, due to the COVID-19 pandemic normal functioning of the courts could not happen and hence new cases in 2020 were much less than in preceding years, pendency increased because disposal rate was even slower than the rate of new cases filed.

It is pertinent to note that in the High Courts, $42 \%$ of the total sanctioned posts for judges were vacant (465 out of 1,098). Five High Courts (Telangana, Patna, Rajasthan, Odisha, and Delhi) had more than 50\% vacancies. High Courts of Meghalaya and Manipur had no vacancies.

As on February 20, 2020, in subordinate courts, $21 \%$ posts out of the sanctioned strength of judges were vacant $(5,146$ out of 24,018). Amongst states having a sanctioned strength of at least 100 judges, subordinate courts in Bihar had the highest proportion of vacancies at $40 \%$ (776), followed by Haryana at 38\% (297) and Jharkhand at 32\% (219). ${ }^{3}$ 
2. Administrative issues: According to the report published by the Supreme Court of India, the subordinate judiciary does not have a sufficient number of courtrooms, support staff and residential accommodation for judges, which results into having hurdles in dispensing justice in time. The report estimates the subordinate judiciary would require more than 5000 courtrooms to accommodate more than 20000 judicial officers. The existing Court rooms are not adequate to cater the present requirement. It is also necessary to fill 40000 staff positions, which are not filled for so many years. The lack of human resources is one of the prominent issue to be resolved on the urgent basis to minimize the pendency in the courts.

3. Infrastructural problems: For smooth and effective court administration, adequate infrastructure is essential, so that all incidental activities necessary to proceed the legal cases in the courts are carried smoothly. Traditional way of functioning also takes time in dealing and processing of the cases. Trained staff with new technology driven processes are nothing but the need of the day. The low budget allocation towards the judicial infrastructure makes situation more difficult, as a result delay occurs in delivering the judgments by the courts in time.

4. Adjournments: Every case has to proceed as per the procedural requirement and stages stipulated by the statute like civil procedure code. Approach of lawyers and sometimes of litigants towards seeking adjournments adversely affect the speed of disposal of the case in the court. There is tendency to initiate or file false and frivolous cases in the courts which takes courts' time unnecessarily. Granting frequent adjournments for one or another reasons also aggravates the situation of pendency of cases in the courts.

5. Legal awareness: Due to increasing literacy rate and growing sensitivity of ones rights, people are keen to fight for justice and hence number of cases are increasing on this count also. There is high number of cases being filed against the various government authorities. The government is one of the biggest litigants in the judicial administration. Awareness is also necessary in the beaurocratic system to deal with this problem. Citizens should also be encouraged to resolve their disputes through conciliation mediations.

6. Growth in the crime rate: There has been continuous rise in the crimes. There was a $46 \%$ rise in complaints of crimes against women in the first eight months of 2021 over the corresponding period of last year. Growth in crimes create heavy burden on the police machinery as well as on the criminal courts. Delay in disposal of criminal cases also increase burden on the prisons' administration in the country.

Considering the prevalent issue of pendency it is the need of the day to find out the ways and means to tackle the issue and suggest improvement in the system through various ways. Pendency is a problem that requires different perspectives and strategic planning so as to make improvement in the judicial administration. All the major reasons for the increasing pendency rate can be dealt with some advancement in the procedure and perspective in legislative, administrative and judicial reforms. 


\section{Suggestions for the reforms:}

1. Increasing number of working days and shifts of courts. The number of days in the courts should be increased so that more productive days will be utilized for disposal of the cases. Courts can work in more than one shift by having additional appointments of judicial officers an even on holidays. Concept of fast track court can also be extended to all sorts of cases including to that of the civil nature.

2. Appointments of Courts managers and trained administrative staff: The appointment of court managers have been made at various courts. It will show some positive picture as trained management professionals would take some proactive steps for the improvement in the present state of affair. With a view to improve Justice Delivery System and enhancing the efficiency of Courts and to have improvement in case disposals, the posts of court managers have been created to assist judges under the scheme of 13th Finance Commission .The court managers will support the judges to perform their administrative duties, thereby enabling the judges to devote more time to their judicial functions. It is expected that this trained management professional would bring positive reforms in court administration and would also be of help in reducing the pendency of cases in the courts.

3. Ad-hoc judges: Article 127 and 128 of the Constitution of India talks about appointment of ad-hoc appointments of the Supreme Court and the High Court judges. These appointments may be made from the eligible and retired judges, however these provisions have not been adequately utilized for minimizing the pendency of cases.

4. Time bound disposal: It is advised to decide the time frame of every case of a routine matters. All stakeholders will be given specific time and all of them will have to follow the time line to dispose the matters on time. Annual action plan for disposal of cases should be framed well in advance and monitoring system to check this plan should be in place to see that cases are decided on time as per the plan. Use of information technology would be of great help in doing this. Target for the disposal of cases may be fixed well in advance and adhered in dispensing the cases to tackle the issue of pendency.

5. Provision of adjournment to be strictly followed.: As per the provisions of the the Code of Civil Procedure order 17 (1) and (2) if followed strictly, situation would definitely improve as the said rule states that the adjournment of hearing in a case not be given for more than three times to parties. Even the provision of imposing costs of adjournment is required to be adhered to so as to discourage the litigants in asking for unnecessary adjournments.

6. IT enabled judicial administration: Information technology enabled services and administration in the courts would help minimize the delay in deciding cases. Technique of artificial intelligence can be utilized for deciding the stereotype cases. In the backdrop of COVID-19 pandemic, our courts have started functioning in Virtual mode and E-Submissions of documents, written on line arguments, on line hearing can help to speed up the disposal rate of the cases. "National Policy and Action Plan for Implementation of Information and 
Communication Technology (ICT) in the Indian Judiciary-2005" has already aimed to have vision to transform the Indian Judiciary by ICT enablement of Courts. The e-Courts Mission Mode Project, is a pan-India Project, monitored and funded by the Department of Justice, Ministry of Law and Justice, for the District Courts across the country. However it has been observed that due to connectivity issue and technological difficulty the virtual court hearings are not happening effectively to the satisfaction of the stakeholders. The Government approved the computerization of 14,249 district \& subordinate Courts under the project by March 2014 with a total budget of Rs. 935 crore. The objective of the e-Courts project is to provide designated services to litigants, lawyers, and the judiciary by universal computerization of district and subordinate courts in the country and enhancement of ICT enablement of the justice system.

The Phase-II of the Project has been approved by the e-Committee of Supreme Court of India in January 2014 for further enhancement of ICT enablement of Courts with a broad objective of Computerization of more than 8000 new courts, legal service authority offices, and state judicial academies with strengthened hardware. It is aimed to connect all the Courts in the country to the National Judicial Data Grid through WAN and additional redundant connectivity to enable integration with the proposed interoperable criminal justice system.

The e-Courts National Portal has a provision for providing Training material to judicial officials and staff, connections to District Court sites, and measurable reports that can be utilized as a judicial administration data framework. This Portal is expected to see major change in the procedural aspects of the courts. Time required for serving notices or summons should be minimized by incorporating new provisions so that even the e-communication of the services of notices be considered as acceptable service of notices as maximum time of the case spent on this stage only. Filing of the cases via electronic medium tracking system of the case progress can be monitored through the electronic mode or through digital means only. All the data relating to the status of the case should be available in the electronic mode.

Video conferencing in courts for conducting cases in the court can be of great help as it would save time of litigants and unnecessary commutation at the cost of traffic and pollution on the roads. The video conferencing between jails and courts started long back in the year 2003 in Maharashtra and it has harnessed good results. Computerization of non-adjudicatory processes in judicial administration should be promoted on priority basis to save the time of judicial processes.

7. A case of Maharashtra: The state government of Maharashtra has set a leading example long back in 2009 of $\mathrm{E}$-governance project and accordingly executed the mission of computerization of courts in Maharashtra. The project touched 350 talukas and district courts through 450 servers, 4000 clients and was implemented by 8000 court employees. Data of 44 lakhs cases fed into the system and made it accessible to pubic on its website. The website contains Judgments and orders which are stored in portable document format (pdf) for the benefit of the stakeholders. This has helped the Maharashtra state to execute its scheme of "Litigation free village" as the data is available on the website. ${ }^{7}$ The concept of $24 x 7$ working 
and access to the court system is possible and it is yielding good results. In the next phases, standardization of various stages in the court proceedings in various courts could be effectively implemented to enhance the functioning of the judicial process. The efforts of Maharashtra state in this regard are worth emulating.

8. Unique identification number for a case: Litigants, lawyers and researchers can access.15 digit unique case identification number, allotted to the litigant. It is useful for tracking the proceedings of his case in the courts. This has helped the lawyers to monitor and manage their work in their office efficiently.

9. Adequate Infrastructure: Well to-do state of art courts rooms with adequate space and facilities for the litigants, lawyers and the court staff be provided. A quality infrastructure can enhance the efficiency of the human resource ultimately helping the system to enhance the efficiency. Adequate budgetary provision are required to be made for judicial reforms including provision for infrastructural improvements.

10. Appointment of judges: Appointments of judicial officers or judges at all levels be taken place on time and no vacancies be lying unattended for a longer period as it has adverse impact effect on timely disposal of cases.

11. Use of ADR mechanism effectively: Alternative disputes Redressal mechanism has certainly helped in minimizing the burden of pendency of cases in the courts. This can be done in the following manner:

i) Mandatory pre litigation mediation be introduces at all levels. : Recently the Consumer Protection Act of 2019 has a provision of mediation and panel of mediators is expected to be formed. Similar provisions are required in every court so that unnecessary litigations can be prevented by effective mediation machinery. This mediation mechanism should be mandatory before the matter is taken for formal adjudication. In this method, Legal Services Authorities can regulate the inflow of the cases into court by conducting pre-litigation mediation. ADR should be followed in order to discourage litigation.

ii) Lok Adalats should be frequently organized and they should become the regular affair and parties should be encouraged to go for lok adalat to resolve the issue amicably. It has been observed that lok adalats are not successful in certain areas, there is apprehension in the minds of members of the Bar that their earnings are likely to be reduced due to settlement of disputes through this mode. The mechanism should ensure some benefit to the lawyer's being the court officer so that he can play better role in enhancing participation of the stakeholders in popularizing the lok-adalat as an effective way of resolving disputes.

iii) Setting up Gram Nyayalayas be encouraged so that rural disputes are not coming to the courts and people should not waste time on unproductive things just because of ill advice or out of ignorance of the legal provisions. Such nyayalayas will be an effective and efficient way to minimize the cases from rural areas.

iv) Establishment of the Legal care and counselling centres by NGOs can also be a great help in reducing the number of cases coming from the rural area. 
v) Setting up more tribunals, Fast Track Courts (FTCs) and Special courts would be of great help for better disposal of the important cases in a faster and more efficient manner.

\section{Conclusion}

Overburdening of the judiciary with pendency is required to be prevented by predetermined policy and strategy. This is necessary to keep the faith of common man in the judicial system. If decisions are delayed beyond reasonable time people will lose the faith in the judiciary and such phase is not good for the healthy society. It's imperative now to take immediate steps to address and resolve these problems so that people don't lose their faith in the judiciary. Proactive, consistent efforts on the part of government, lawyers and litigants can play vital role in improvement in the overall judicial administration in the country. ADR, Conciliation and mediation are require to be used as the effective tools to reduce the pendency in the Indian courts.

\section{References:}

1. PRS Legislative Research data dated October,11, 2021

2. ibid

3. ibid

4. https://www.latestlaws.com/articles/how-to-reduce-the-pendency-in-the-courts\#

5. https://main.sci.gov.in/statistics

6. https://www.news18.com/news/explainers/explained-cji-ramana-says-4-5-crore-casespending-heres-what-has-been-fuelling-backlog-3977411.html

7. Justice Chavan, R.C., "Cries in Wilderness" (2015), Hind Law House, Pune

8. https://en.wikipedia.org/wiki/E-courts_In_India 